\title{
The efficacy of strategic management processes: An empirical study of National Sports Associations of Zimbabwe.
}

\author{
Edmore Nhamo ${ }^{1}$, Margaret Tinny Muswazi ${ }^{2}$ \\ ${ }^{I}$ Department of Health Sciences, Faculty of Science and Technology, Zimbabwe Open University, P.O Box \\ 3550, Bulawayo, Zimbabwe. \\ ${ }^{2}$ Department of Health Sciences, Faculty of Science and Technology, Zimbabwe Open University, Bag MP \\ 1119, Mt Pleasant, Harare, Zimbabwe.
}

\begin{abstract}
The purpose of this study was to appraise the adequacy of strategic management processes of National Sports Associations (NSAs) in Zimbabwe. Most of Zimbabwe NSAs perform poorly as evidenced by the perennial failure of national teams to qualify for major regional and international tournament. Their strategic management processes appear to be inadequate to meet the modern day environmental challenges. The study used the descriptive survey as the design. A sample of fifty three National Sports Association and Provincial Sports Association chairpersons were randomly selected from a population of seventy nine chairpersons. Hand delivered questionnaires with both open ended and closed questions were used to collect data. Results from the study indicate that most NSAs have core values, corporate objectives, policies and make use of physical structures. However the results also show that the majority of NSAs do not have strategic plans, do not practice strategic management and do not conduct strategic reviews. The results led to the conclusion that the strategic management processes in NSAs are inadequate. The study recommended that NSAs should prioritize strategic management and that both the Sports and Recreation Commission and Zimbabwe Olympic Committee should assist NSAs technically and financially to facilitate the adoption of strategic management principles.
\end{abstract}

Keywords: National Sports Associations, strategic control, strategic implementation, strategic management, strategic planning, Zimbabwe

\subsection{Background to the study}

\section{Introduction}

According to the Sports and Recreation Commission (SRC) Act of 1996, "National sports Associations means any group or body of persons operating in Zimbabwe and having as their principal object the promotion or organisation on a national basis of any particular sport or any recreational activity" Zimbabwe National Sports Associations (NSAs) are therefore voluntary non profit making bodies charged with the responsibility of developing sport in Zimbabwe. Their major role is to control and manage sport at national level and to promote the sport to potential and existing spectators and fans, developing players and organizing national championships. At international level National Sports Associations are affiliated to the relevant international federations. At national level the National Sports Associations are registered with the Sports and Recreation Commission. In terms of the Sport and Recreation Commission Act, the mandate of the Parastatal is among others to control, regulate, assist, promote, coordinate and generally oversee the promotion and development of sport and recreation in the country. The Sports and Recreation Commission also ensures the proper administration of organizations undertaking the promotion of sport and recreation and promotes the highest standards of sportsmanship and governance. It is the supreme sporting body of the country.

As articulated by SRC (2008) the inception of the Sport and Recreation Commission and the subsequent enactment of Statutory Instrument 342 of 1995 and the physical education, sport and recreation policy of 2006 created an enabling enviroment for the National Sport Associations to develop sport. This enviroment provided for the decentralisation of structures and programmes by National Sport Associations to provincial and district levels in an attempt to close the gap between the grassroots level activity and mainstream sport. However inspite of this enabling enviroment, National Sport Associations have not made meaningful progress as they are yet to link their national programmes with grassroots activities (SRC, 2008). It has also been observed that Zimbabwean teams in general are perenial non achievers and have failed to qualify for and impress at major regional and international events. One of the possible reasons for this poor perfomance could be the fact that National Sports Associations do not seem to think and manage strategically.

According to shalomsoundproject (2010) the success of sport depends upon three factors: organisation, management and administration. It is noted that out of these three factors, management is the most important as it is concerned with planning and programming, policy formulation and coordinating activities. It also includes control of work perfomance and maintenance of discipline for purposes of delivering satisfactory quality sport. shalomsoundproject (2010) also analysed the problems that are experienced by sports organisations and 
identified management as the most important.They argue that the problems that are seen at management in sports associations are the root cause of all problems in sport today.

There are numerous sport gorvening bodies in many coutries, including Zimbabwe, which operate very unprofessionally and this seams to be a very common problem in developing countries. The Zimbabwe Olympic Committee (ZOC) an administrative National Sport Association in collaboration with Olympic Solidarity introduced an advanced diploma in sport management which targets National Sports Association Executives in Zimbabwe in order to enhance their management and governance skills. It is important to note that strategic management is one of the key modules of this advanced management course. The programme was introduced in apparent recognition of the management gap existing within NSAs.

According to Kanhukamwe and Zvomuya (2004) Sport is one of the fastest growing industries in the world. Sports organisations like all other business organisations are operating in an enviroment that is volatile, unpredictable and turbulent(more so in Zimbabwe), thereby making strategic management imperative. As Nedela (2009) explains, "the advantages of first-rate strategic thinking and a deep commitment to the strategic management process include the guidance it provides to the entire management hierarchy in making clear just what it is the company is trying to do and to achieve."

It is against the above background that sports organisations like other business entities have found themselves enganging in strategic management. Sports organisations such as the Sports and Recreation Commission the Zimbabwe Olympic Committe and the Zimbabwe Cricket Union have been enganging in strategic management for quite some time now. However local literature is quiet about strategic management in the majority of the National Sports Associations, thereby creating a gap that needs to be filled in by local research.

\subsection{Purpose of the study}

The purpose of this study was to establish the adequacy of strategic management processes of National Sports Associations in Zimbabwe. Strategic management is becoming more and more of a sine qua non in today business organisations (sports organisations included). These organisations are operating in unpredictable and turbulent enviroments especially so in Zimbabwe. This makes the measurement of the efficacy of their strategic management processes imperative. The only way an organisation can predict the future is by creating the kind of future they would like to see and there is no better way of creating a desirable future than strategic planning and management.

\subsection{Statement of the problem}

NSAs in Zimbabwe have failed to meaningfully decedentralise their activities to the grassroots. They have failed to attract meaningful corporate sponsorship. National teams have failed to qualify for major regional and international tournaments such as the Africa Cup of Nations and FIFA World Cup in soccer. Is poor strategic thinking and management one of the reasons why National Sport Associations are failing to deliver? This question seem to be begging for an answer which this particular study will hopefully provide.

\subsection{Research questions}

(a) Do Zimbabwe NSAs plan strategically?

(b) Do Zimbabwe NSAs manage strategically?

(c) Do Zimbabwe NSAs conduct strategic measurement and control?

\subsection{The concept of strategic management.}

\section{Review of related literature}

According to Dess, Lumpkin and Taylor (2005) Strategic management consists of analysis decisions and actions an organisation undertakes in order to create and sustain competitive advantages. Cole (1997) on the other hand defines strategic management as a process directed by top management, which is used to determine the fundamental aims or goals of the organisation and ensure a range of decisions which allow for the achievement of those aims or goals in the long term, whilst providing for adaptive responses in the shorter term.

A review of the various definitions on strategic management leads to the understanding that the essence of strategic management includes a strategy formulation stage, the realization of the strategy as dictated by implementation of recommendations and the management of the changes required to make the processes actually work. This implies philosophies of management, theoretical concepts, associated techniques, competitive analysis, planning processes and the management of change.

\subsection{The strategic management process}

According to Dess et al (2005) the strategic management process consists of three major ongoing processes which are: strategy analysis, strategy formulation and strategy implementation. This means that 
strategic management is concerned with the analysis of strategic goals (vision, mission and strategic objectives) along with the analysis of the internal and external environment of the organisation. Next, leaders must make strategic decisions. Smith (2001) lists the following tasks of strategic management: developing the strategic vision, translating the vision and mission statement into measurable objectives and performance targets, crafting a strategy to achieve the desired results, effective and efficient implementation of the chosen strategy and evaluating performance, reviewing new developments and initiating adjustments. All these tasks imply strategic decision making. Kuveya (2002) opines that Strategic Management is considered a cycle of decisions where each set of decisions has an effect on subsequent decisions as well as having consequences for all those affected by them.

\subsection{The importance of strategic management}

According to Nonprofit (2002) strategic management is a tool used to help an organisation do a better job, to focus its energy so as to ensure that all members of the organisation are working towards the same goals and to assess and adjust the organisation's direction in response to its changing environment. Nedela (2009) explains that the advantages of first-rate strategic thinking and a deep commitment to the strategic management process include the guidance it provides to the entire management hierarchy in making clear just what it is the company is trying to do and to achieve. He goes on to emphasize that the advantages also include the contribution it makes to recognizing and responding to market changes, new opportunities, and threatening developments, the rationale it provides for management in evaluating competing requests for investment capital and new staff. The advantages also include the coordination which it adds to the entire strategy-related decision making done by managers across the organisation and the proactive instead of reactive posture that it gives to the organisation. In addition Nedela (2009) argues that high-performing companies use their knowledge and global expertise to deliberately try to impact their target markets with a powerful strategy; they try to initiate and lead, not just react and defend.

\subsection{The strategic planning process}

Strategic planning can be defined as the establishment of objectives and the formulation, evaluation and selection of polices, strategies, tactics and action required to achieve these objectives (Kuveya 2002). Johnson and Scholes (1997) as cited by Kuveya (2002, P: 13) summarize the characteristics of strategic planning and decisions for an organisation as follows:

Strategic planning must be concerned with the scope of the organisation's activities, strategic

planning involves the matching of an organisation's activities to the environment in which it operates.

Of interest is their identification of a number of steps that can be taken in order to successfully carry out strategic planning which include:

setting corporate strategies/objectives, establishing targets, internal appraisal, external appraisal, forecasting future performance, analyzing the gap between targets internal resources and performance, identifying and evaluating the various strategies, choosing between alternative strategies, preparing the final corporate plan, implementing the chosen strategies and finally evaluating actual performance against the corporate plan.

Farrah, Greenstein, Hirsche dettaan, Levi, Matsumoto, Rosen, Sppington, Schwarting and Warren (2011) state that strategic planning is more than ensuring your association will remain financially sound and be able to maintain its reserves. They further state that it is a process of projecting where your association expects to be in five, ten, or fifteen years, and how your association will get there. They also emphasize that strategic planning is a systematic planning process involving a number of steps that identify the current status of the association. The other steps include identification of mission, vision for the future, operating values, needs (strengths, weaknesses, opportunities, and threats), goals, prioritized actions and strategies, action plans, and monitoring plans.

Farrah et al argues that strategic planning is the cornerstone of every common interest community such as a National Sports Association. He argues that without strategic planning, the community will never know where it is going; much less know if it ever got there. In addition Farrah et al opine that an important concept of strategic planning is an understanding that in order for the community to flourish, everyone needs to work to ensure the team's goals are met.

\subsection{Benefits of the long-range plans}

Farrah et al (2011) highlights the following benefits of strategic plans as indicated by Bernard and Steiner, (1986). Farrah highlights that long range planning is important because it stimulates thinking to make better use of the association's resources, assigns responsibility and schedules work, coordinates and unifies efforts. In addition he also highlights important factors such as the facilitation of control and evaluation of the 
association's activities (accountability), the creation of awareness of obstacles to overcome, the identification of opportunities, the avoidance of the trap of linear thinking and the facilitation of progressive advancement of the association's goals.

\subsection{Strategic vision}

Kotelnikov (2001) defines a corporate vision as a short succinct and inspiring statement of what the organisation intends to become and to achieve at some point in the future. He states that a vision is often stated in competitive terms and refers to the category of intentions that are broad, all inclusive, and forward thinking. $\mathrm{He}$ also explains strategic vision as the image that a business must have of its goals before it sets out to reach them. According to Kotelnikov (2001) a vision describes aspirations for the future, without specifying the means to be used to achieve those desired ends.

Ray (2000) gives a more detailed description of a vision as a concise statement that describes the ideal state which an organisation aspires to. It describes the preferred future of an organisation, one which is better than its current existence. Ray argues that by establishing a vision to aim for, the organisation is showing full commitment and shaping the roadmap for a successful future. He goes further to give the following characteristics of a vision: Clear specific and realistic statement of accomplishment and outcomes, not strategies or activities, written in the present tense of how the organisation looks upon reaching the vision, a challenging level of achievement but not over challenging with a reasonable time frame.

\subsection{Business mission}

Ray (2000) defines a mission statement as a written expression of an organisation's philosophy, purpose and characteristics. He explains that a mission is a brief clear statement of the purpose of the organisation or the function of the organisation. Ray states that this statement of purpose describes the primary business or thrust of the organisation and its reasons for being. According to Ray (2000) the mission statement should answer the following three questions which are: what is the business of the organisation? For whom is the organisation in business? And how does the organisation fulfil its function?

According to strategic.gc.ca (2004) a mission statements outlines what the company is now. They argue that a mission statement focuses on today. In addition they also explain that a mission statement identifies the customer, identifies the critical processes and it states the level of performance. Kotelnikov (2000) on the other hand avers that a mission statement is an organisation's vision translated into written form. He goes further to argue that a vision makes concrete the leader's view of the direction and purpose of the organisation. This statement shows clearly the inseparable relationship between a vision and a mission statement.

\subsection{Core values/guiding principles}

According to Strategic Alignment Inc (2002) values are part of culture and are stated preferences and the actual behaviour of people and how people act and how things are done. Orans (1996) describes values as those things that really matter to each of us, the ideas and beliefs we hold as special, such a caring for others and freedom to express our opinion. Kanhukamwe and Zvomuya (2006) give a more comprehensive description of values by saying that values represent a statement of care, beliefs and convictions. The above definitions seem to lead to several conclusions including the following. The descriptions suggest that values establish moral and ethical principles that serve to guide activities. In addition it can also be concluded that values describe what is right and wrong, important and unimportant. Values are concerned not only with self regulation but also with interpersonal conduct. Lastly the literature reveals that values are universal and impartial, and examples include sportsmanship, justice, freedom, equality, fairness, fair play and others.

According to Farrah et al (2011) values are also called guiding principles. These values state the association's intentions and expectations. They are used to judge the association's policies and actions, as well as individual conduct. Farrah argues that associations should include values such as: the importance of customers and customer service; commitment to quality and innovation; importance of honesty; integrity and ethical behavior; corporate citizenship; respect for the employee and the duty the association has to its employees; and importance of safety and protecting the environment.

\subsection{Strategic aims and goals}

Thetimes100 (1995) defines a business aim as the goal a business wants to achieve. The Strategy Unit (2004) states that "as the desired state of the future are described in the vision, strategic aims and objectives are therefore needed to define those things that need to be achieved in order to bring it about". The strategic Unit emphasizes that a small number of broad aims need to be supported by a range of more specific objectives defined over the short, medium and long term. They argue that at this stage the primary concern is 'what' needs to be achieved rather than 'how', which will be more fully addressed through policy design. However, they note that some broad appreciation of the policy packages that might deliver each objective will help to ensure that 
realistic objectives are set. In addition, some sense of the likely level of support for each idea will provide an indication of its chances of success. Ray, (2000) is of the opinion that goals are derived from the mission statement; they are general statements of intent. McNamara (n.d) on the other hand expresses that goals are general statements about what an organisation needs to accomplish to meet its purpose or mission and address major issues facing the organisation. McNamara goes further to argue that goals need to be both long-term and short-term. Six months, one-year, three years, and ten-year goals need to be set so that the strategy for reaching these goals can be outlined in the plan. It can be noted from the literature reviewed that most authorities recommend setting the long-term goals first and then setting short-term goals i.e. those goals which can be reached as steps to attaining the long-term goal. However Kelly (2008) thinks that objectives and goals are interchangeable. He describes goals as the ends toward which effort and action are directed or coordinated.

\subsection{Strategic objectives}

According to thetimes100, (1995) a business objective is a detailed picture of a step you plan to take in order to achieve a stated aim. The Business Directory.com (2011, p: 1) cite Drucker (2004) as saying: strategic objectives are, in general, externally focused fall into eight major classifications: (1) Market standing: desired share of the present and new markets; (2) Innovation: development of new goods and services, and of skills and methods required to supply them; (3) Human resources: selection and development of employees; (4) Financial resources: identification of the sources of capital and their use; (5) Physical resources: equipment and facilities and their use; (6) Productivity: efficient use of the resources relative to the output; (7) Social responsibility: awareness and responsiveness to the effects on the wider community of the stakeholders; (8) Profit requirements: achievement of measurable financial well being and growth.

Smith and Malaba (2001) express that once the organisation has set its vision and mission, the next stage in the process is to set strategic objectives, which represent management's commitment to achieving specific outcomes and results. These two authors go further to say that it is important to note that objectives that an organisation sets for itself should be related to the mission statement of the organisation. Objectives can be set for all key areas that an organisation is involved in. Smith and Malaba (2001) cite Thomson and Strickland (1999) as pointing out that for objectives to function as yard sticks of organisational performance, they must be stated in quantifiable terms and must contain a deadline for achievement. Thetimes100 (1995) also emphasize that objectives need to be SMART in order for the business to know what progress it has made towards achieving the objective. Thetimes100 (1995, p: 1) defines the acronym SMART as follows:

Specific which refers to clear and easy to understand, measurable which means able to be quantified, achievable which imply possible to be attained, realistic which means the objective must not be a pie in the sky and time bound which is associated with a specific time period.

While other authors talk about setting SMART objective The Strategic Unit (2004) emphasize that it is important to set objectives that are: suitable, feasible and acceptable and they define these terms as follows: Suitable - addressing key issues and able to deliver desired outcomes, Feasible - achievable with potential organisational and system resources, Acceptable - with the support of those with the authority and influence to legitimize. It is apparent that both authors are in some form of agreement as the strategic Unit describes a SMART objective in similar but alternative sort of way.

\subsection{Corporate strategy}

Strategic Alignment Inc (2002) defines strategy as "the direction and scope of an organisation over the long term, which achieves advantages for the organisation through its configuration of resources within a changing environment to meet the needs of markets and fulfil stakeholder expectations."

Nickols (2003) presents and highlights Minzberg's five dimensions of strategy commonly referred to as the five Ps of strategy. The first "P" refers to strategy as a plan. According to Nickols when strategy is referred to as a plan it is a unified, comprehensive and an integrated plan designed to ensure that the basic objectives of the enterprise are achieved. The second "P" refers to strategy as a ploy. Nickols explains that as a ploy, strategy takes us into the realm of direct competition where threats, feints and various manoeuvres are employed to gain advantage. The third "P" as Nickols avers, refers to strategy as a pattern which is specifically a stream of actions. The fourth "P" refers to strategy as a position which is a means of locating the organisation in what organisational theorists call the environment. The fifth "P" refers to strategy as perspective where it's content consists of not just a chosen position but an ingrained way of perceiving the world particularly in as much as perception shape and guide decisions and actions.

According Smith and Malaba (2001), crafting a strategy is the how of achieving the proposed plan. They explain that objectives are the ends and the strategy is the means. They further argue that when an evaluation of a company's strategy is done, one has to start with a solid analysis of the internal and external situation of the organisation. Strategy has to be both proactive (intended) and reactive (adaptive) because reality rarely turns out as planned. Crafting a strategy is a deliberate process. 
Pettigrew, Schendel, Van de Ven, Chakravarty and Doz, (1992) are cited by Gibsbert (2002) as arguing that the three generic steps in the strategy making process (envisaging, conceiving, and realizing) were derived from a review of existing work in the strategy process realm. They state that process research in strategic management is concerned with how effective strategies are shaped within the firm and how they are then efficiently implemented. The Small business-marketing-plans.com (2007) also recognize the existence of offensive and defensive strategies. They cite Kotler and Singh (1999) as having identified five offensive and six defensive strategies which are named after military strategies such as offensive warfare and defensive warfare.

\subsection{Strategy implementation and execution}

Hanver is cited by 1000ventures.com as asserting that "The vision must be followed by the venture. They emphasize that "it is not enough to stare up the steps, we must step up the stairs." mystrategicplan.com avers that implementation is the process that turns strategies and plans into actions in order to accomplish strategic objectives and goals. They argue that implementing a strategic plan is as important, or even more important, than the strategy. The critical actions move a strategic plan from a document that sits on the shelf to actions that drive business growth. Sadly they observe that the majority of companies who have strategic plans fail to implement them. Mystrategicplan.com concurs with the above authors and goes on to identify five key components necessary for effective strategic implementation but which are often overlooked. The five key components are, people, resources, structure, systems, and culture". The above writers stress that all components must be in place in order to move from creating the plan to activating the plan. According to Glatstein (2006) it is only half of the success to develop a good strategy. Execution is equally important, since it can make or break the best strategy. Glatstein (2006) goes on to cite Hrebiniak (2001) as saying that many of today's top executives are far better at developing strategy than executing it and overcoming the political and organizational obstacles that stand in their way.

\subsection{Strategic control}

Gregory et al (2005) explain that the strategic control step involves evaluating perfomance, reviewing new developments and initiating corrective adjustments of the strategic plan. They go further to suggest that organisations must have effective strategic controls if they are to successfully implement their strategies. They also further emphasise that strategic control includes systems that exercise both informational control and behavioural control. They identify two approaches of informational control, namely the traditional approach and the contemporary approach. The first approach which they term traditional is highly sequential. In this approach goals and objectives are set then implemented and after each set period of time perfomance is compared to the desired standards. In contrast the contemporary approach is much more interactive. It involves continuous monitoring of the internal and external enviroment while managers dertemine whether the strategy itself needs to be modified. The day to day contemporary approach is reqired given the rapidly changing conditions in virtually all industries.

Behavioral control on the other hand is described by Gregory et al (2005) as a process where a firm strives to mantain a proper balance between culture, rewards and boundaries Gregory et al also argue that organisations that have strong positive cultures and reward systems can rely less on boundaries such as rules, regulations and procedures. When individuals in the firm internalise goals and strategies, there is less need for monotoring behaviuor as efforts are focused more on important organisational goals and objectives. Behaviour control attempts to ask if the organisation is doing things right in the implementation of its strategy.

\subsection{Research design}

\section{Methodology}

A research design as explained by McMillan and Scumacher (1993), refers to a plan of selecting subjects, research sites and data collection procedures to answer the research questions. In order to answer the research questions in this study the desriptive survey design was used. The survey design was used to study a given population of NSAs Chairpersons and made use of randomly selected samples. The descriptive survey was considered appropriate because it has the following characteristics: As Chikoko and Mhloyi (1995) aver, "survey research uses as data gathering whatever will yield quantifiable information such as interviews, observations and questionnaires". So the choice of this methodology for this particular study allowed some degree of freedom of choice in selecting data gathering instruments. They go further to emphasise that, surveys are commonly used when studying social phenomenon and is probably the best method which is available to use in collecting original data for purposes of describing a population too large to observe directly.

\subsection{Population}

The population of this study was made up of all the National Chairpersons, their administrators or representatives of the fifty nine National Sport Associations registered with the Sport and Recreation 
Commission and the twenty one Provincial Chairpersons of all Provincial Sports Associations found in Bulawayo. This constituted a total study population of 79 individuals. The population was considered appropriate in line with the definitions and descriptions offered by various authors. Harper (1992) and Hussey and Hussey (1997) describe a population as a precisely defined group of people or iterms about which we want to obtain information.

\subsection{Sample}

In this study forty two (42) Chairpersons were selected by means of random sampling method from the National Association and eleven (11) Provincial Board Chairpesons from the Provincial Sports Associations automatically qualified making a sample of (53) fifty three. The sample in this study was defined in conformity with Chikoko and Mhloyi (1995) who define a sample as a subset of the total population, which should display characteristics of the population.

\subsection{Sampling procedure}

59 names of all National Sports Associations were written on pieces of paper and and the papers placed in a bowl. Forty two pieces of paper were hand picked from the hat by a blind folded individual to constitute part of the research sample. For the Bulawayo population the same procedure described above was used to select ten Associations initially for the pilot study. Since the total population of Provincial Sports Associations in Bulawayo is 21, this effectively left 11 Provincial Sports Associations to constitute the balance of the sample for the main study. The eleven Provincial Sports Association were identified first. The names of these Associations were then removed from the Population of 59 NSAs. A random sample of 42 was then selected from the remaining 48 NSAs. This was done in order to ensure that no association had two respondents as this would bias the results. The sampling was done in line with Borg and Gall (1989) who define sampling as a process of selecting a number of subjects from a defined population which is representative of that population.

This study made use of a simple random sampling method where each possible unit from the population had an equal chance of being selected.The sampling frames from where the sample was drawn were the register of National Sport Associations and the Bulawayo register of Provincial Sports Associations obtainable from the Sports and Recreation head office and Bulawayo province Sports and Recreation Commission offices respectively. Bulawayo province was purposively sampled out of the ten provinces of Zimbabwe because of its proximity to the researcher. The size of the sample was dertemined in conformity with suggestions given by Krejcie and Morgan (1970). Krejcie and Morgan (1970) developed a table for determining sizes of a randomly selected sample from a given finite population of $\boldsymbol{N}$ cases such that the sample proportion $\boldsymbol{p}$ will be within plus or minus 0,05 of the population proportion with a $95 \%$ level of confidence.

\subsection{Research instrument and data collection procedure}

This study made use of the questionnaire as a principal data collection instrument. The questionnaires ware hand delivered to the respondents and consisted of both open ended and closed items. Most of the items on the questionnaires consisted of Yes/ No responses which attempted to force respondents to state the actual status quo without leaving room for being evasive. the questionnaires were distributed during a National Sports Associations quarterly meeting. Follow up hand deliveries were done to sampled associations who did not attend the meeting. The administration style enabled a ninety four percent response rate ie fifty questionnaires were completed and returned out of fifty three sampled.

\subsection{Data analysis techniques}

In this research figures representing the responses from the questionnaire were extracted. The figures were summarised by means of tables . The data was then textually and analytically described, discussed and interpreted to review their meaning and to identify the adequacy of strategic management processes in the National Sports Associations

\subsection{Demographic profile}

\section{Results}

The table below shows the sample distribution by position occupied in the NSAs. The data was collected in order to ascertain the suitability of the respondents to this study.

Table 4.1 Showing sample distribution by position

\begin{tabular}{|l||l||l||}
\hline Position & No of respondents & percentage \\
\hline \hline Chairperson & 19 & $36 \%$ \\
\hline \hline Vice Chairperson & 9 & $18 \%$ \\
\hline \hline Secretary & 10 & $20 \%$ \\
\hline \hline Vice secretary & 2 & $4 \%$ \\
\hline
\end{tabular}




\begin{tabular}{|l||l|l||}
\hline Treasurer & 5 & $10 \%$ \\
\hline \hline Committee member & 2 & $4 \%$ \\
\hline \hline Other & 3 & $6 \%$ \\
\hline
\end{tabular}

Data from table 1 above indicate that eighty six percent of the respondents were made up of chairpersons, secretaries and treasurers ( bona fide NSAs strategic leadership) The rest of the respondents were either committee members or administrators of the NSAs. All respondents were found to be suitable as they had first hand information about their National Associations.

\subsection{Adequacy of Strategic planning}

The data presented below cover issues to do with the adequacy of strategic planning. Table 4.2 Fig 4.1, Table 4.3, Table 4.4 and Table 4.5 show data on adequacy of the strategic planning process in terms of availability of a current strategic plan, vision, mission statement and values.

\subsubsection{Availability of a strategic plan and reasons for lack of one}

Table 4.2 showing the availability of a strategic plan

\begin{tabular}{|l||l|l|l|}
\hline \multicolumn{1}{|c||}{ Item } & Responses & Frequency & percentage \\
\hline \hline \multirow{2}{*}{$\begin{array}{l}\text { Availability of a } \\
\text { strategic plan }\end{array}$} & YES & 5 & $10 \%$ \\
\cline { 2 - 4 } & $\mathrm{NO}$ & 45 & $90 \%$ \\
\hline \multicolumn{2}{|c|}{$\mathrm{N}=50$}
\end{tabular}

Data from table 4.2 above shows that $90 \%$ of the respondents indicated that their National Sports Associations do not have a current strategic plan.

The respondents who indicated above that they do not have a strategic plan cited the following reasons as barriers to strategic planning. The reasons are shown in figure 1 below:

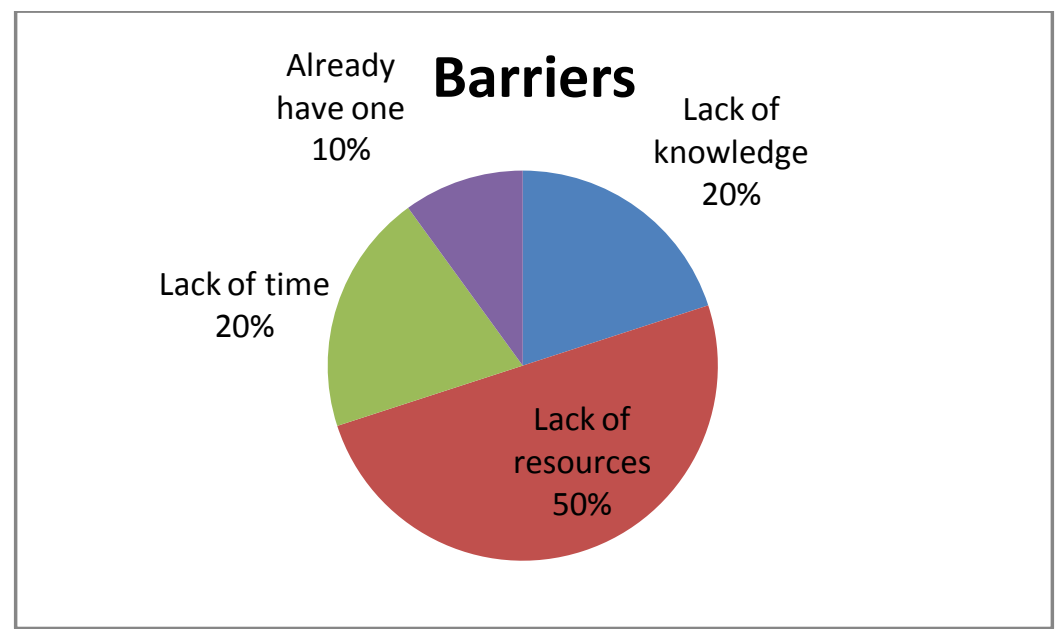

Figure 4.1 Showing reasons for lack of a strategic plan

Data in figure 4.1 above show that fifty percent $(50 \%)$ ) cited lack of resources as their most important barrier to strategic planning. Twenty percent (20\%) cited lack of time while another twenty percent (20\%) cited lack of knowledge, $10 \%$ indicated that they already have a strategic plan.

\subsubsection{Availability of corporate vision and statement of the vision}

Table 4.2 Showing availability of a corporate vision

\begin{tabular}{|c|c|c|c|}
\hline Item & Responses & Frequency & percentage \\
\hline \multirow{2}{*}{$\begin{array}{ll}\text { Does } & \text { your } \\
\text { organisation } & \text { have } \\
\text { a vision? } & \end{array}$} & YES & 5 & $10 \%$ \\
\hline & $\mathrm{NO}$ & 45 & $90 \%$ \\
\hline
\end{tabular}

Ten percent of the respondents agreed that their National Sports Association have a corporate vision. Ninety percent indicated that their National Sports Association has no Vision. The ten percent (10\%), who indicated that they have a corporate vision, stated their visions as follows: 
"To be a competitive and world class National Association brand that represents the country with sporting excellence,"

"To be a leading National Sports Association"; to be the leader in providing opportunities for members to enjoy personal and professional growth",

"To be the country's leading producer of sporting Excellency and talent development".

In summary the stated visions concentrated more on talent identification and sporting Excellency.

\subsubsection{Availability of a mission and statement of mission}

Table 4.3 Showing availability of a mission statement

\begin{tabular}{|l|l|l|l||}
\hline \multicolumn{1}{|c|}{ Item } & Responses & Frequency & Percentage \\
\hline \hline $\begin{array}{l}\text { Availability } \\
\text { of } \begin{array}{l}\text { Ifion } \\
\text { mission } \\
\text { statement }\end{array}\end{array}$ & YES & 5 & $10 \%$ \\
\cline { 2 - 4 } & NO & 45 & $90 \%$ \\
\hline
\end{tabular}

Ninety percent indicated that their National Sports Association has no mission statement. The ten percent (10\%), who indicated that they have a mission statement, stated their mission statement. Some of the mission statements were stated as follows: to provide our valued supporters with a vibrant national team through well established structures and well organized talent identification and nurturing; To inspire, lift and provide the platform and tools for talent identification, development, growth and performance excellence; to provide a national platform where practically any one talented in the sport can participate and develop.

\subsubsection{Organisational values}

Data in table 4.4 below show responses on organizational values which contribute to the adequacy of the strategic plan.

Table 4.4 Showing core values

\begin{tabular}{|l|l|l||l||}
\hline Item & Responses & Frequency & Percentage \\
\hline \hline $\begin{array}{l}\text { Availability of } \\
\text { appropriate } \\
\text { values or guiding } \\
\text { principles }\end{array}$ & YES & 40 & $80 \%$ \\
\cline { 2 - 4 } & & 10 & $20 \%$ \\
\hline \multicolumn{2}{|c|}{$\mathrm{N}=50$} & & \\
\hline
\end{tabular}

Data in table 4.4 above show that eighty percent of the respondents agreed that their National Sports Association have values or guiding principles that dictate the way members behave. The eighty percent respondents who indicated that their National Sports Association has values listed some of the following values: Fair play, fairness, integrity, teamwork, honesty.

\subsection{Strategic implementation process}

The following data show responses on the adequacy of the strategic implementation process in terms of corporate objectives, polices, operational plans, full time employees and physical structures.

\subsubsection{Objectives and policies}

Table 4.5 Showing availability of objectives and corporate policies

\begin{tabular}{||l||l|l|l||}
\hline \hline Items & Responses & Frequencies & Percentage \\
\hline \hline $\begin{array}{l}\text { Availability of } \\
\text { corporate objectives }\end{array}$ & YES & 50 & $100 \%$ \\
\cline { 2 - 4 } & NO & 0 & $0 \%$ \\
\hline \hline $\begin{array}{l}\text { Availability of } \\
\text { corporate policies }\end{array}$ & YES & 50 & $100 \%$ \\
\cline { 2 - 4 } & NO & 0 & $0 \%$ \\
\hline
\end{tabular}

According to the data in table 4.6 above one hundred percent (100\%) of the respondents indicated that their National Sports Associations have corporate objectives, corporate policies and operational plans. Most of the NSAs indicated that they have legal policies, press policies, talent identification policies, policies dealing with ethical issues and human resources policies. 


\subsubsection{Operational plans}

The table below shows results on operational planning which is necessary for strategic implementation.

Table 4.6 Showing availability of operational plans

\begin{tabular}{|c|c|c|c|}
\hline \multirow{2}{*}{$\begin{array}{l}\text { Availability } \\
\text { of } \\
\text { operational } \\
\text { plans }\end{array}$} & YES & 50 & $100 \%$ \\
\hline & $\mathrm{NO}$ & 0 & $0 \%$ \\
\hline
\end{tabular}

Data in table 4.7 above show that one hundred percent of the respondents indicated that they have operational plans.

\subsubsection{Number of full time employees}

Eighty percent $(80 \%)$ of the national associations surveyed in the study indicated that their national sports association depends on volunteers only and does not employ any full time staff (secretariat). Only twenty percent indicated that they have some full time staff working at the association.

\subsubsection{Physical structures}

Table 4.7 Showing availability of physical infrastructure

\begin{tabular}{|c||l||l|l||}
\hline \multicolumn{1}{|c|}{ Item } & Responses & frequencies & percentage \\
\hline \hline $\begin{array}{l}\text { Availability } \\
\text { of physical } \\
\text { infrastructure }\end{array}$ & YES & 50 & $100 \%$ \\
\cline { 2 - 4 } & NO & 0 & $0 \%$ \\
\hline
\end{tabular}

One hundred percent of the respondents indicated that they have physical structures which they make use of. One hundred percent indicated that they use playing fields and office infrastructure. The next question sought to establish the form of ownership of the physical structures mentioned above. Eighty percent $(80 \%)$ indicated that they make use of rented facilities while only twenty percent own the facilities they use.

\subsection{Strategic monitoring and control}

The table below shows results on strategic monitoring and control.

Table 4.9 Showing strategic plan review

\begin{tabular}{|c|c|c|c|}
\hline Item & Responses & frequencies & percentage \\
\hline \multirow{2}{*}{$\begin{array}{l}\text { Conduct of } \\
\text { strategic plan } \\
\text { reviews }\end{array}$} & YES & 5 & $10 \%$ \\
\hline & NO & 45 & $90 \%$ \\
\hline
\end{tabular}

Data from 4.9 above indicate that ten percent (10\%) of the national sports associations surveyed engage in strategic plan review sessions. Ninety percent $(90 \%)$ indicated that they do not engage in strategic plan review. These responses tally with the responses to question two which indicated that only twenty percent of the respondents have a strategic plan whilst eighty percent do not have and therefore do not have anything to review.

\section{Discussion of findings}

The study attempted to assess the efficacy of strategic management processes in Zimbabwe National Sports Association by focusing on three major strategic management processes. The three processes were strategic planning, strategic implentation and strategic control.

Findings showed that $90 \%$ of the NSA surveyed do not have a current strategic plan while only $10 \%$ do have. The findings indicate a serious gap because it implies that the marjority of the NSAs are operating without strategic plans. Literature reviewed in this study showed that lack of a strategic plan can be a source of organisational failure. As argued by Farrah et al (2011) strategic planning is the cornerstone of every common interest community. He argues that without strategic planning, the community will never know where it is going; much less know if it ever got there.

Fifty percent of NSAs surveyed cited lack of resources as the main barrier to strategic planning. The findings reveal that lack of resources is a significant barrier.

As revealed by the findings the majority of NSAs are operating without visions and missions. The NSAs are therefore, according to Ray (2000) not showing commitment to shaping the roadmap for a successful 
future. In addition lack of a mission statement indicates lack of commitment to express the organisation's philosophy, purpose and characteristics, thereby failing to articulate the primary business of the organisation,

On the contrary findings on core values or guiding principles indicate that the majority $(80 \%)$ have core values which guide the way business is practiced. The NSAs are doing very well in this regard even though the source of these values is not clear since most NSAs indicated that they do not have strategic plans with vision and mission statements. This area obviously needs further research. However, the availability of values is positive because according Kanhukamwe and Zvomuya (2006) values establish moral and ethical principles that serve to guide activities. Findings show that all NSAs indicated that they have objectives and policies which guide their day to day operations. However, it is the source of these objectives and policies which is not clear because, naturally they are supposed to be derived from the strategic plan. As indicated by Ray (2000), objectives/ goals are statements of intent derived from the mission statement.

Data obtained show that all NSAs indicated that they have operational plans. Again, the operational plans seem to have no basis because according to the hierarchy of plans, they are supposed to be derived from the strategic plan. Since most of the NSAs do not have strategic plans the basis of the operational plans becomes questionable. From this study suggests that eighty percent of NSAs depend on volunteers or part time staff. Only twenty percent have full time employees who are responsible for the day to day running of the Associations. This is a weakness, because according to Mystrategic plan.com the first stage in implementing any plan is to make sure that there are the right people on board. Volunteers are full time employees elsewhere and their commitment to the association may be questionable, which probably explains why most NSAs are performing poorly. As reflected in the findings all NSAs have physical structures which they make use of. However results also indicate that the majority of these NSAs do not own the facilities but make use of rented facilities.

Ninety percent of NSAs surveyed do not conduct any form of strategic review or control, most likely because, as reported earlier, they also do not have the plans to review. Gregory et al (2005) suggest that organisations must have effective strategic control systems if they are to successfully implement their strategies.

\section{Conclusions}

On the basis of the findings the following conclusion was drawn:

The strategic management processes of NSAs are inadequate. This is because while the majority of National Sports Associations have core values, corporate objectives, polices and make use rented physical structures it can also be observed from the overall findings that the majority of NSAs do not have strategic plans, vision statements, mission statements, full time employees, physical structures of their own and do not conduct strategic reviews, thereby making their strategic management processes inadequate. This study therefore concludes that the efficacy (effectiveness and ability to meet expected standards) of the strategic management processes of NSAs is highly questionable.

\section{Recommendations}

From the above findings it is recommended that:

National Sport Associations should prioritize strategic management with effect from 01 January 2013.

$>$ The Government, through the Sports and Recreation Commission, should assist the NSAs technically by facilitating strategic planning workshops for them and designing training programmes in strategic management with effect from 01 January 2013.

$>$ The SRC and ZOC should assist NSAs by providing the financial resources to facilitate strategic planning and management.

> The Zimbabwe Olympic Committee should follow up their advanced sports management graduates and assist them implement the strategic management principles acquired during the course by conducting follow up training workshops.

\section{References}

[1]. Government of Zimbabwe (1996) Sports and Recreation Commission Act, Zimbabwe.

[2]. Sport and Recreation Commission (2008) Community Sport Development Manual, SRC: Belvedere. Harare.

[3]. Shalomsoundproject (2010) Key problems facing sports today,(on line) [retrieved on the $8^{\text {th }}$ of November 2011] from http//www: sportsnexus.wordpress.com

[4]. Kanhukamwe and Zvomuya (2004) Sports Marketing and Management. Zimbabwe Open University. Mount Pleasant Harare

[5]. Dess. G. G, Lumpkin, G. T and Taylor, M. L (2005) Strategic Management, New York: McGraw-Hill/Irwin

[6]. Cole, G. A, (2000) Strategic Management Theory and Practice London: Lens Educational Aldine Place

[7]. Smith K.G Baum J.R and Locke, E.A (2001) A multidimensional model of venture growth, Academy of management Journal: in press

[8]. Kuveya, T, (2002) Strategic Management. Zimbabwe Open University. Mount Pleasant Harare

[9]. Noneprofit (2002) strategic management (online) [retrieved on the $19^{\text {th }}$ of December 2010] from http//www.nonprofit.com

[10]. Jonhson, G and Scholes, K, (2002) Exploring Corporate Strategy ,New York: Prentice Hall PTR, 
[11]. [Farrah J; Felix R; Greenstein A; Hirsche de Haan E; Levi E; Matsumoto E; Burd Rosen J; Sppington C; Schwarting and warren D (2011) Best practices Report \# 3,strategic Planning, Foundation for Community Association Research (on line) [retrieved on the $8^{\text {th }}$ of November 2011] from www.cairf.org

[12]. Kotelinikov. V, (2001) Corporate vision, mission, goals and strategies. (on line) [Retrieved on 10 October 2011] From http://www.1000ventures.com/business

[13]. Ray G (2000) Vision, Mission and Goals (online) [retrieved on 5 August 2011] from http://ezinearticles.com

[14]. Strategies.gc.ca (2004) Steps to competitiveness (online) [retrieved on 1o December 2011] from http://www.ic.gc.ca

[15]. Strategic alignment Inc (2006) the leadership context (online) [retrieved on 04 August 2011] From http://www.strategicalignment.com

[16]. [16].Orans, P.L (1996) what are values (online) [retrieved on 8 November 2011] from http://wwwpinefreeweb.com

[17]. The times 100 (1995) Creating business objectives (online) [retrieved on $29^{\text {th }}$ of June 2012] from www,thetimes100,co.uk

[18]. The strategy unit (2004) Strategic aims and objectives, (online) [retrieved on the 27 of December 2011] form www.thestrategyunit,com

[19]. Kelley, B (2008) Mission Vs. Goals. Vs. Objectives Vs. Strategy Vs.Execution (online ) [ retrieved on the $8^{\text {th }}$ of September 2012] from www.aef.com/industry

[20]. Smith, A and Malaba, J (2001) Strategic Management. Zimbabwe Open University. Mt Pleasant. Harare

[21]. Thompson and Strickland, (1997) Strategic Management Concept and Cases. McGraw - Hill/Irwin Professional Publishers. New York

[22]. Nickols F (2003) definitions and meaning of strategy (online) [retrieved on the $11^{\text {th }}$ of February 2012] form www.chris-kimble.com

[23]. Henry Mintzberg five Ps for strategy in the strategy process, Mintzberg H and J.B Quinn (Eds) (1992) Prentice hall international Editions: Englewood Cliffs NJ,

[24]. Kotler and Singh (1999) Offensive and Defensive Strategies (on line) [retrieved on the11 $1^{\text {th }}$ of November 2011] From http://www.smallbusiness-marketingplans.com

[25]. Mystrategic plan.com strategic implementation (online) [retrieved on the $10^{\text {th }}$ of June 2013] from www.mystrategicplan.com/resources/strategic-implementation

[26]. Glaststein, S (2006) Business Strategy Execution: 4 reasons why your company's strategy isn't working (online) [retrieved on the $10^{\text {th }}$ of may 2012] from www.themanager.org

[27]. Chikoko and Mhloyi (1995) Research methods, Zimbabwe Open University, Mt pleasant Harare

[28]. Borg, W.R. and Gall, M. D. (1989) Educational Research. New York: Longman 